\title{
ASSESSMENT OF THE STATE OF A TECHNICAL OBJECT USING THE BALANCE OF ITS TECHNOLOGICAL EFFICIENCY OF OPERATION
}

\author{
S. Voinova ${ }^{1}$ \\ ${ }^{1}$ Odessa National Academy of Food Technologies, Odessa \\ ORCID: ${ }^{1}$ 0000-0003-0203-0599 \\ E-mail: ${ }^{1}$ voinova_s@yahoo.com
}

Copyright (C 2014 by author and the journal "Automation technological and business - processes". This work is licensed under the Creative Commons Attribution International License (CC BY). http://creativecommons.org/licenses/by/4.0/

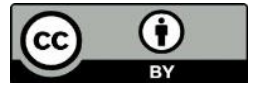

ONAFT

Open Access

Abstract: The content, meaning and methodological possibilities of use of the developed and proposed balance of technological efficiency of operation of a technical object are considered. The methodological basis for offset in different conditions and modes of use of technical objects, with different properties are described. Content, features and mutual relations of the resulting indicators of the state of these objects are disclosed. The potential positive technical and scientific possibilities of the use of offset's results when new technical objects are created or worn-out objects are updated are noted. The offset and use of the closing, instantaneous and the prognosis balance of technological efficiency of technical object's operation broaden scopes, deepens the possibilities of analysis and control of this process.

Keywords: Balance, technological efficiency, functioning, technical object, offset, updating, control.

Introduction

During the current stagnate period of the development of production the used equipment in a significant part is worn physically out, therefore the problem of increase of a level of its technological efficiency (TE) is actual. Increase of a level of technological efficiency of the processes proceeding in technical objects (TO), lags behind from increasing requirements to it. Condition of elimination of similar backlog is increase of quality of control by functioning TO. For the decision of this problem it is necessary to develop approaches, methods, and means of research, the analysis and an assessment of a condition of studied object, level its TE of functioning. Thus it is necessary to receive the developed information as well about a level of parameters of a condition and object's TE in the set point in time, as the information about their level during an analyzed interval of time.

TE (Et) TO is a combination of three components: ecological efficiency (El), economic efficiency (En) and generaltechnical efficiency (Egen). In each point in time each component is characterized by the certain level of its leading property (the certain physical value).

Statement of problem

In production owing to physical wear TO, the level of each component TE decreases in time that reduces level object's TE as a whole. Thus, pace of decrease in a level of each of components is original and depends on power of influence on it of influencing factors. The specified factors shape complicated process of influence of all conditions of passing of technological process on each component and on level TE TO as a whole.

Level TE TO in each point in time is defined by its condition, its properties defining a level of its El, En, Egen. It testifies to importance of measurement, research and a critical assessment of properties, that is conditions TO as control object. The urgency of a problem of the current control of a condition and level TE TO is obvious.

Level TE TO characterizes its functional properties, technological possibilities. Therefore control of it is control of a condition TO. According to the traditional approach, about a TO condition they speak by duration of the period of its actual use. At achievement of the period equal to a resource of efficiency appointed by a manufacturer (R) they consider reached a limiting condition and a subject full updating, that is replacement by new object. The similar approach differs by ultimate simplicity and accessibility, but carries in itself danger of mistake in definition of a current condition TO by the time its inspections. However practically while in TO operation it is possible in set point in time by means of technical diagnostics to 
define its current condition, to measure a level El, En and Egen, that is to establish its level Et in an a moment of inspection. It is valuable, but the narrow information.

Incomparably wider is the accumulated information about level Et TO for the surveyed fulfilled interval of time or for all period of an spending $\mathrm{R}$ by it. In this case it is necessary to have also the information on variations Et (T), variations its properties in time $(\mathrm{T})$ that is level Et, during an investigated site of a trajectory.

Solutions to problems

For the solution of similar problems it is necessary to know consistent patterns of variation of TO properties in time (with influence of wear), caused by its variation its Et, that is it is necessary to know dynamics of process of its wear. Studying of these laws is the subject matter of scientific discipline - technical gerontology.

During functioning TO it collects the result of realization its TE. That is, efficiency, volume its used TE (V) grows in time. This important rated volume reflects the saved up useful effect of functioning TO, of realizations of its efficiency in the made volume of production.

In the elementary, ideal case when TO would work without wear, that is, it would work at Et, equal initial TE of new TO (Eini), volume its TE (in a considered interval of time) would be maximal (theoretical) - Vini. In this case the coefficient of use of efficiency TO (E) is equal $\mathrm{E}=(\mathrm{V} / \mathrm{Vini}) 100=100 \%$. In this case it takes place the ideal balance between initial TE TO and used (actual) one. Balance TE TO (BTE) kept up in an ideal version: the used volume V is equal to initial volume Vini. The equation of balance TE TO in this (first) case looks like: V=Vini.

As experience has shown, a highly effective working method above offsetting BTE TO is its graphic interpretation formation of diagram BTE in coordinates « parameters of technological process TO - time ». Offset BTE allows to distinguish neatly the components of technological process which influence on its result, to see their interaction, to see a complex of the rated values influencing an end result of technological process with participation TO.

Let's analyse briefly potential capacities and results of use BTE in characteristic cases, for three regimes of operation TO: a regime $\mathrm{A}$ - regular, regime $\mathrm{B}$ - irregular and regime $\mathrm{C}$ - in actual industrial conditions. We'll characterize primary results of the analysis.

Regime A. It was offset and researched BTE of functioning TO in a regular regime for three characteristic conditions of its application [1]:

Conditions 1. TO functions in following conditions:

- regular regime (conforms set by a manufacturer of object),

- wear is absent,

- flexible control (algorithm of automation control system is adapted for character of wear TO in time) [2].

Conditions 2. TO functions in following conditions:

- irregular regime,

- wear takes place,

- control is flexible with which automation control system algorithm is adapted for character of degree variation of wear TO in time [4].

Conditions 3. TO works in actual industrial conditions:

- regular regime,

- wear takes place,

- control is hard with which automation control system algorithm isn't adapted for character of degree variation of wear TO in time $[1,2]$.

Regime B. It has been offset and investigated BTE of functioning TO in an irregular regime for three characteristic conditions of its application [3].

Regime C. It has been offset and investigated BTE of functioning in a regime of actual industrial conditions, for three characteristic conditions of its application [4].

Carried out complex research has allowed to get into deep features of process of functioning TO in different conditions and different regimes. For preparation and use of all ample opportunities BTE TO, it is necessary to have character Et (T) TO, which is a product of technical gerontology [5].

BTE opens a complex of properties TO, allows to analyze not receptions, but an essence of TO control process. In research of properties TE TO is necessary to analyze not only parameters of the main thing from its three properties on which level TE TO is established, but to analyze also parameters of two other its properties. The similar control is necessary for maintenance of the specified properties at an appropriate level and in the set parity (among themselves). Particular BTE it is necessary to offset or each of three components TE TO. Work with BTE TO should found on the system approach [6].

Full BTE TO contains three particular BTE, on components. The special attention is required with ecological aspect TE TO, particular ecological BTE [7].

The analysis of information possibilities BTE allows to consider, that diagram BTE is a technological biography of TO. At the same time, it also the planned program of its further appropriate use, down to exhaustion residual R. Diagram BTE TO the developed picture of variation of level its TE, showing how technological possibilities of object have been used to date, what are they at present, as well as what its potential for functioning during an expenditure of a residual resource. Accordingly, the diagram reflects a content of final balance, instant balance and прогнозного balance TE TO. 
BTE TO is the productive tool of comprehensive analysis TE of process of functioning TO.

The analysis of a material offset BTE TO allows in particular, the following:

- to see, open and study a content of its technological process,

- to open a complex of potential technological possibilities created or existing TO,

- to execute the comparative analysis of potential TO posibilities and its actual parameters of work on the passed period and the forthcoming period of expenditure R,

- to estimate quality of a regime of operation and a regime of maintenance service TO; allows to plan ways and means of their improvement during an expenditure of a residual resource.

Theoretical and applied aspects of use BTE are substantial, important. Development of area BTE TO require appropriate attention and resource maintenance.

BTE TO is the comprehensive tool of the scientific and technical analysis of technological properties and possibilities TO, both potential, and realized by the time of their considerations.

There is a basis to consider appropriate to include in the modern computer-integrated system of automatic control by modern TO the BTE block which allow, in particular, to deduce on the display of the automated workplace of the operator The BTE material: diagram Et (T), its elements and the digital information.

As is known, the organizational-technical technology of updating of worned out TO exists. It is the basis to consider as its highly productive progress the technology of offsetting BTE TO offered by the author as tool of control of level TE updated, as well as the created modern equipment.

Conclusions

1. During the present, stagnate period of progress of manufacture the used equipment in a significant part is worn physically out, therefore it poses the problem of increases of its level TE. A developing area of control of TO functioning process poses the problem of expansions and deepenings of process of the analysis of changing properties and level TE of operating TO.

2. For the decision of these two interfaced problems, it is necessary to improve methods, approaches and means of research, the analysis and an assessment of a condition TO, a level of their technological efficiency both in the set point in time, and during the set period of time.

3. Made and offset BTE surveyed TO allows to open, in detail to investigate and analyse a content of technological process carried out with its help, its ecological, economic and general-technical components. It allows to open and analyze not receptions, but elements of TO TE control process, three its components.

4. BTE TO allows to estimate its technological properties and possibilities at the passed operation phase, to measure their level at the moment time and predictionly estimate their potential for the forthcoming period of an expenditure of the residual resource by object.

5. BTE of process of functioning TO is the productive tool of the expanded research of technological properties, the analysis of a condition and an assessment of parameters of TO functioning during the fixed period of time, in a moment of consideration and during the predicted period of its use.

6. Application BTE TO is founded on use of character of variation of TO properties in time with influence of wear. In this connection it is necessary to accelerate development of problems of technical gerontology.

7. Diagram BTE TO reflects how technological possibilities of object have been used to date, what they are in a moment of consideration, as well as what potential for its functioning during an expenditure of a residual resource.

8. Final ВТE allows углубленно, in a complex to analyze and estimate parameters of functioning TO for the considered period of time.

9. Прогнозный ВТЕ allows to organize expediently TO operation and its technical (operational and repair) service during the forthcoming period of its use.

10. For development and progress of potential BTE TO, it is necessary to expand the researches in area of technical gerontology and technical diagnostics. It is necessary to develop and introduce in practical work wide-profile software product, for preparation and use BTE TO in different branches of manufacture and in various conditions of functioning of objects.

11. There is a basis to consider appropriate to include block BTE in modern automation control system of TO.

\section{Referenses}

[1] S. A. Voinova, "Balans tehnologicheskoy effektivnosti tehnicheskih ob'ektov v regulyarnom rezhime," Energetika ta elektrifikatsiya, no. 11, pp. 49-53, 2014;

[2] S. A. Voinova, "Nekotoryie osobennosti gibkogo upravleniya tehnicheskimi ob'ektami," Energetika ta elektrifikatsiya, no. 10, pp. 34-37, 2013;

[3] S. A. Voinova, "Balans tehnologicheskoy effektivnosti tehnicheskih ob'ektov v neregulyarnom rezhime," Energetika ta elektrifikatsiya, no. 3, pp. 37-42, 2015;

[4] S. A. Voinova, "Balans tehnologicheskoy effektivnosti funktsionirovaniya tehnicheskih ob'ektov v realnyih proizvodstvennyih usloviyah," Energetika ta elektrifikatsiya, no. 8, pp. 35-41, 2015; 
[5] S. A. Voinova, "Tehnicheskaya gerontologiya. Potentsial vliyaniya na effektivnost funktsionirovaniya tehnicheskih ob'ektov / Mater. za VI Mezhdunarodna nauchna praktichna konferentsiya «Naynovite postizheniya na evropeyskata nauka-2010», 17 - 25 yuni, 2010g. Tom 20 «Tehnologii. Fizicheska kultura i sport».- Sofiya: «Byal GRAD-BG» OOD, 2010. - S. $79-84$.

[6] S. A. Voinova, Sistemniy pidhid do upravlinnya tehnologichnoyu efektivnistyu tehnichnih ob'ektiv / Fizicheskie i kompyuternyie tehnologii.- Trudyi 17-y Mezhdunarodnoy nauchno-tehnicheskoy konferentsii, 20-21 sentyabrya 2011g.- Harkov: HNPK «FED», 2011.- S.105 - 108.

[7] S. A. Voinova, "Pro aktualnist upravlinnya ekologichnoyu efektivnistyu tehnichnih ob'ektiv," Energetika ta elektrifikatsiya, no. 1, pp. 64-67, 2012.

\title{
MULTILINGUAL RECODING METHOD DESIGNED FOR SCADA-SYSTEM'S SOFTWARE UPGRADE
}

\author{
S. Velykodniy ${ }^{1}$, O. Tymofieieva ${ }^{2}$ \\ ${ }^{1}$ National University "Odessa Maritime Academy", Odessa \\ ${ }^{2}$ Odessa State Environmental University, Odessa \\ E-mail: 1dotsent1981@mail.ru, 25ms11985@mail.ru
}

Copyright (C) 2014 by author and the journal “Automation technological and business - processes". This work is licensed under the Creative Commons Attribution International License (CC BY). http://creativecommons.org/licenses/by/4.0/

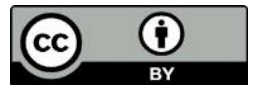

ONAFT

Open Access

Abstract: The article discusses a new approach to upgrade the software for SCADA-systems. A distinctive feature of this method is the ability to support more than ten most popular programming languages. By applying this method it's possible to automate the process of recoding software components and, by doing so, it saves time programmers have to spend to rewrite the code and reduce the likelihood of structural errors inherited from the previous system.

Key words: reengineering, recoding, software component, Supervisory Control And Data Acquisition (SCADA-system), Computer-Aided Software Engineering (CASE-means).

\section{Introduction}

Supervisory Control And Data Acquisition Systems (SCADA-system or SCADA) has been implemented in various fields of human life but the most widespread occurred in industry and on transportation. And SCADA operation for each mode of transportation (by water, air, rail, road) has fundamental differences.

One common feature for all SCADA is that with time its software become outdated under number of factors such as constant update of information systems, changes in programming languages and distributed data processing systems, etc. Inevitable, such trend leads to speed and graphic deterioration, loss of information, communication and time and / or other features decline until complete system failure.

Defining the problem and its relationship with important scientific or practical tasks

Creating SCADA is quite complicated and time consuming process that can be accomplished by highly skilled and wellcoordinated team of developers and coordinators, as only design process included more than ten stages already: research, specification development, technical proposal, preliminary design, technical design, mock-up project, coding, compiling, testing, releasing, and quite often further technical and customer support.

SCADA development is an enormous scientific and technical undertaking which implementation requires significant investment. All existing SCADA and those that are in stage of development using current methodology contain the results of many years of research done by thousands of scientists, engineers, designers and developers who participated in developing 